\title{
Collaboration of Districts in Fulfilling Rajangan Madura Tobacco National Production
}

\author{
Dzikrillah Thoriqur Rahman ${ }^{1) *}$ \& Retno Sunu Astuti2) \\ 1) Master of Public Administration, Faculty of Social and Political Sciences, \\ Universitas Diponegoro, Indonesia \\ 2) Faculty of Social and Political Sciences, Universitas Diponegoro, Indonesia
}

Received: 17 May 2020; Reviewed: 31 May 2020; Accepted: 21 February 2021

*Email Coresponding: dzikrillah.thoriqur95@gmail.com

\begin{abstract}
This study aims to analyze the concept of collaboration between districts in fulfilling the national production of Rajangan Madura tobacco national and to know the factors causing the decline in Rajangan Madura tobacco production. The problems are focused on the decline in tobacco production and the area of agricultural land in each district, and the instability of the price of tobacco which causes anxiety for farmers. The production and area of Madura tobacco farming land has decreased since 2013 with the production produced is only 3.5 tons with an area of $8.4 \mathrm{ha}$. If the accumulated decline in production and the area of tobacco farming land per year has decreased by $15 \%$ of the total normal production per year as much as 29 thousand tons from a land area of 32 hectares in each district.To approach this problem, Wright's theoretical reference was used, there were five key elements in the implementation of intergovernmental relations, namely 1) the roles of government, 2) the interactions of public officials, 3) sustainability communication, 4) the roles administrators, and 5) focus attentions on the policy. The data were collected through observation and literature study and analyzed qualitatively and descriptively. This study concluded that collaboration between districts has shown good cooperation by dividing the roles and tasks of each region. The interaction of public officials had shown cooperation in behavior, beliefs, perceptions and preferences. With regard to the communication that was built from the four regions, looking for ways and solutions to increase Madura tobacco production and prevent instability in the price of Madurese tobacco in the harvest season. This collaboration had a target of achieving the fulfillment of Rajangan Madura tobacco production to increase by thirty percent, namely the production of Madura tobacco in each year was targeted at eighty tons. Three factors caused the decline in Rajangan Madura tobacco production, namely, first, the decline in tobacco prices was a major factor for farmers in producing tobacco. Second, climatic factors also influenced the maturation process of tobacco until it wasready for harvest. Third, the reduction of land owned by the government and the community due to the fulfillment of development in the infrastructure sector.
\end{abstract}

Keywords: Collaboration; Fulfillment of National Production; Madura Rajangan Tobacco; Tobacco Farmers.

How to Cite: Rahman, D.T., \& Astuti, R.S., (2021). Collaboration of Districts in The Meeting of Rajangan Madura Tobacco National Production. Jurnal Administrasi Publik (Public Administration Journal).11(1):11-21. 


\section{INTRODUCTION}

Country Indonesia is an archipelago country that has a diverse population and culture. The historical record of the State of Indonesia is also known as a population who has an income in agriculture. The land area of Indonesia from Sabang to Merauke, from Miangas Island to Rote Island, has an area of $1,919,440 \mathrm{~km} 2$, used for the development of cities / regencies, housing residents, industry, agriculture and etc. (https://id.wikipedia.org/wiki/Indonesia)

Indonesian agriculture according to data from the Ministry of Agriculture's Center for Data and Information, in 2014 stated that the area of agricultural land at that time reached 43.5 million hectares with 10.1 million hectares of rice fields, 12.9 million Tegal / Kebun, 6.25 million hectares of rice fields and unprocessed temporary land. 14.25 million hectares, then the area of agricultural land in Indonesia has taken up $23 \%$ of the land area in Indonesia. (pusdatin.pertanian, 2014)

The existence of the data above is not surprising if Indonesia ranks 6th (sixth) as a tobacco producer with a land area of 195,620 Ha. With a total tobacco production of 230,000 tons / year. Indonesian tobacco products are able to contribute $2.67 \%$ of tobacco leaves from global supply. The tobacco industry also contributes to state revenue of Rp. 148 Trillion, that number reaches $8.92 \%$ of the total of State Budget in 2018. The following is data on Indonesian Tobacco from some of the largest tobacco producing provinces in Indonesia. (Komunitas_kretek.or.id)

TEMBAKAU INDONESIA

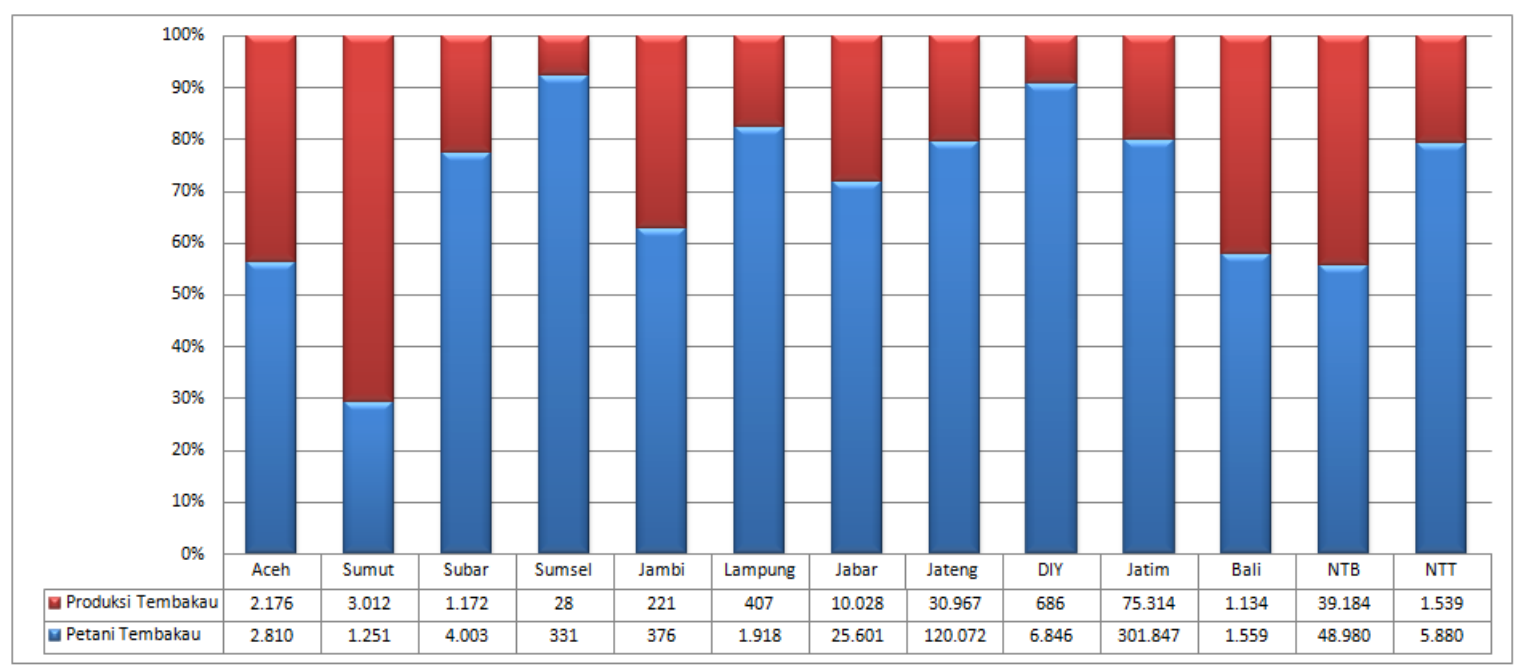

Figure 1 Diagram of Indonesian Tobacco Source:https://komunitaskretek.or.id

Analyzing the data above indicates that the largest tobacco production and number of tobacco farmers in Indonesia is East Java Province, where the number of tobacco farmers is 301,847 people with a land area of 91,6241 hectares and the total production produced annually is 75,314 tonnes of tobacco.
The total amount of this abundant production was the participation of districts that are widespread in the East Java region, with around 29 districts. However, not all districts are tobacco producers. The following is data on the 10 largest tobacco-producing districts in East Java Province in a period of ten years from 2006 to 2015. 
Table 1. Tobacco Producing Districts in East Java

\begin{tabular}{|c|l|c|c|c|c|c|c|c|c|c|c|c|}
\hline \multicolumn{2}{|c|}{ Kabupaten/Kota } & $\begin{array}{c}\mathbf{2 0 0 6} \\
\text { (Ton) }\end{array}$ & $\begin{array}{c}\mathbf{2 0 0 7} \\
\text { (Ton) }\end{array}$ & $\begin{array}{c}\mathbf{2 0 0 8} \\
\text { (Ton) }\end{array}$ & $\begin{array}{c}\mathbf{2 0 0 9} \\
\text { (Ton) }\end{array}$ & $\begin{array}{c}\mathbf{2 0 1 0} \\
\text { (Ton) }\end{array}$ & $\begin{array}{c}\mathbf{2 0 1 1} \\
\text { (Ton) }\end{array}$ & $\begin{array}{c}\mathbf{2 0 1 2} \\
\text { (Ton) }\end{array}$ & $\begin{array}{c}\mathbf{2 0 1 3} \\
\text { (Ton) }\end{array}$ & $\begin{array}{c}\mathbf{2 0 1 4} \\
\text { (Ton) }\end{array}$ & $\begin{array}{c}\mathbf{2 0 1 5} \\
\text { (Ton) }\end{array}$ & $\begin{array}{c}\text { Total } \\
\text { Produksi }\end{array}$ \\
\hline $\mathbf{1}$ & Pamekasan & 10.805 & 16.561 & 17.057 & 12.270 & 10.242 & 16.688 & 19.236 & 3.642 & 15.018 & 13.940 & 135.459 \\
\hline $\mathbf{2}$ & Jember & 364 & 452 & 7.668 & 7.620 & 7.235 & 15.846 & 31.284 & 18.297 & 19.939 & 18.511 & 127.216 \\
\hline $\mathbf{3}$ & Probolinggo & - & - & 13.427 & 11.691 & 9.805 & 7.835 & 10.336 & 9.528 & 13.098 & 12.160 & 87.880 \\
\hline $\mathbf{4}$ & Bojonegoro & 333 & 855 & 7.732 & 10.427 & 3.857 & 15.218 & 11.216 & 5.292 & 9.210 & 8.550 & 72.690 \\
\hline $\mathbf{5}$ & Sumenep & - & - & 13.210 & 6.575 & 3.139 & 9.247 & 13.392 & 3.230 & 9.430 & 8.755 & 66.978 \\
\hline $\mathbf{6}$ & Sampang & 12.989 & 20.029 & 5.880 & 5.908 & 5.670 & 3.002 & 2.702 & 2.202 & 2.896 & 2.689 & 63.967 \\
\hline $\mathbf{7}$ & Situbondo & 10.171 & 8.631 & 1.224 & 3.725 & 4.920 & 7.488 & 8.856 & 2.287 & 5.015 & 4.656 & 56.973 \\
\hline $\mathbf{8}$ & Lamongan & 38 & - & 2.876 & 1.471 & 2.053 & 7.331 & 13.704 & 4.856 & 7.053 & 6.548 & 45.930 \\
\hline $\mathbf{9}$ & Bondowoso & 954 & 1.330 & 4.323 & 5.339 & 3.736 & 7.440 & 4.123 & 5.607 & 4.967 & 4.611 & 42.430 \\
\hline $\mathbf{1 0}$ & Jombang & 339 & 595 & 2.231 & 4.065 & 604 & 2.401 & 4.519 & 4.740 & 7.110 & 6.601 & 33.205 \\
\hline
\end{tabular}

Source: data processed from BPS East Java (2006 - 2015)

Data Table 1 shows that the largest tobacco-producing center in East Java Province is Madura Island. In table 1, the highest ranking of the largest tobacco producer is Pamekasan Regency with a total production for ten years of 135,459 tons. Therefore, if the total production is calculated every year, tobacco farming in Pamekasan district produces 16 tons per year. Large production was the role of farmers in cultivating agricultural land and maintaining the quality of tobacco, it triggers good economic growth in agriculture in Madura.

Tobacco production on the island of Madura sometimes decreases due to various obstacles, if a decrease in production occurs it will create a scarcity of tobacco and lead to a reduction in cigarette factory production. The decline in the production of Rajangan Madura tobacco has caused Pamekasan Regency to take concrete steps to establish cooperation with districts in the Madura region such as
Bangkalan, Sampang and Sumenep districts to bring back the heyday of Madura tobacco. Through the Regional Coordination Agency (BAKORWIL) which is based in Pamekasan District, the concept of collaboration between districts is discussed and its objectives are conveyed.

In building cooperation in the agricultural sector, it will provide a good contribution to each region, especially to the fate of tobacco farmers, with collaboration between districts will boost the welfare of tobacco farmers and there will be a legal umbrella that provides clarity from production to Madura tobacco trading. It cannot be denied that from the four districts in Madura region that have clear regulations on Madura tobacco is only Pamekasan Regency. The existence of this regulation will provide an example for other districts to bind tobacco farmers with existing regulations, so the rights of farmers are protected by the local government. 


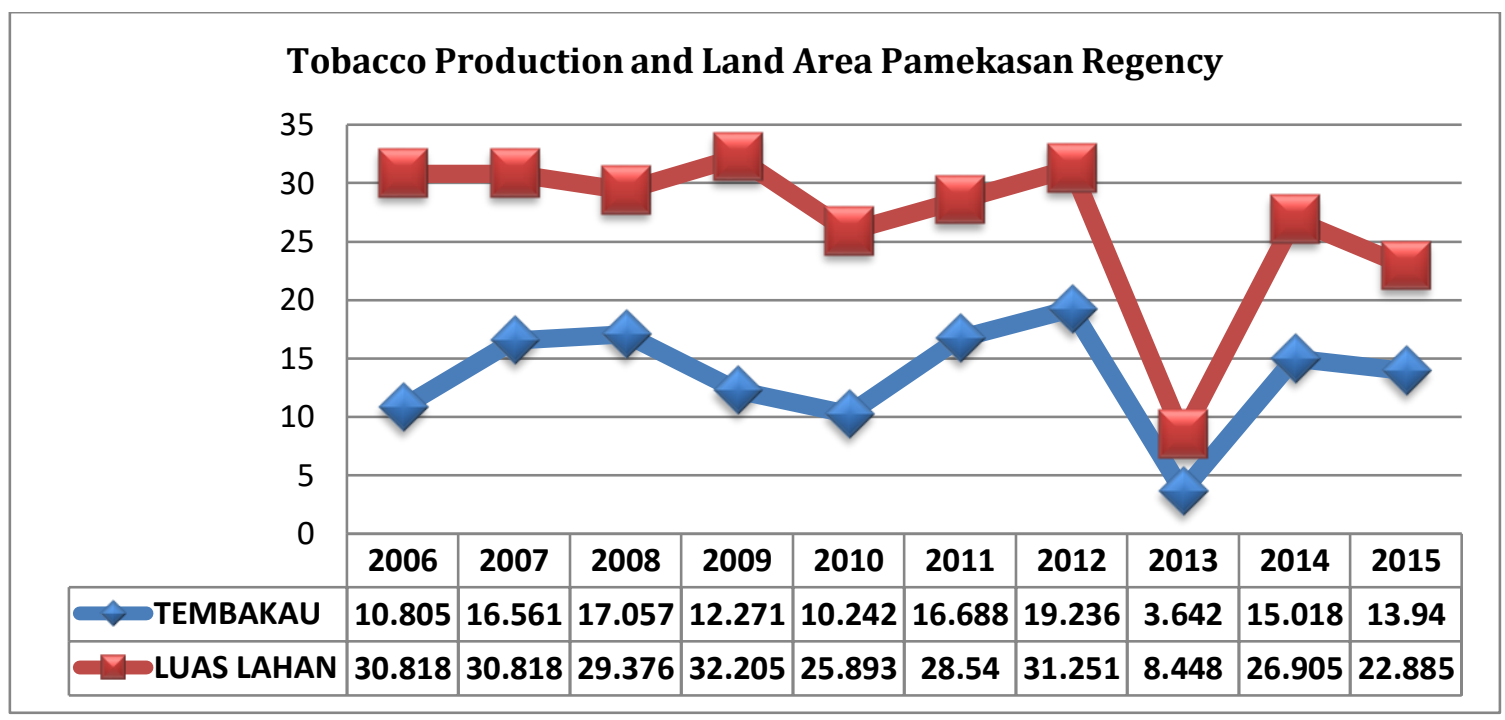

Figure 2 Production Diagram and Tobacco Farming Area

Source: Data Processed by BPS Pamekasan Regency (2006 - 2015)

Figure 2 is presented to observe the fluctuations in production and land area of Pamekasan Regency which is currently still the largest contributor district in the region Madura or on East Java Province. Analyzing the production and area of Madura tobacco farming in Pamekasan Regency, after looking for the causes of the decline in tobacco production and agricultural area, it turns out that the influence of weather is the main factor in the failure of the tobacco harvest, furthermore in 2013 Pamekasan Regency tried its luck by planting sugar cane. To be able to expand profits in agriculture, but it had experienced the failure, where a lot of sugarcane fields failed due to the mismatch of soil structure and a lot of sugarcane was burned because the dry season easily created sparks on dry peatlands such as sugar cane. This factor added to the loss agriculture for the Pamekasan district government.

So the rate of decline in production from 2012, the initial production of tobacco was 19,236 tons with a land area of 31,251 hours and decreased in 2013 by about $70 \%$ with a production figure of 3,642 tons with a total area of tobacco farming at that time only 8,448 hectares.

Problems are starting to emerge in the Madura tobacco farming sector, data from table 1 and figure 2 explain the decline in production experienced by four districts in
Madura Island, this will reduce the supply of tobacco in terms of Indonesian cigarette production. In fact, according to data from the Ministry of Industry, the market demand for tobacco reaches 300,000 tons per year, this figure will continue to grow according to market demand. Meanwhile, Indonesia's agricultural production only reaches 200,000-230,000 tons per year. This decline in production will force the central government to continue importing tobacco, if the tobacco import policy is implemented every year it will have a negative impact on the authenticity of Indonesian tobacco and affect the value of the local tobacco market.

The regional cooperation of the four districts on the island of Madura must be synergized in terms of Madura tobacco farming to meet market needs. Given that Madura tobacco is the best variant in terms of aroma and taste, each district in Madura Island must work together and provide policies for tobacco farmers to increase their production.

Law $23 / 2014$ on Regional Government also provides opportunities for districts / cities to collaborate with districts / cities, provinces and the central government. Not all the resources needed by the regions in developing or organizing public services are owned by the regions, therefore the regions need other regions to 
produce what they want. There are limitations to the public expenditure budget in a region so that if one region has the same goal, cooperation is the answer to efficiency in the use of the regional budget. These things make the regions concerned feel the need to coordinate and cooperate in implementation and efforts to achieve some of the regional wishes that have emerged.

This regulation is a support for the cooperation between Madura Regency in Fulfilling Madura Tobacco Production in order to contribute to abundant production and to fulfill the desires of the national market.

Therefore to answer the problems studied and answer the question "how is the collaboration between districts in fulfilling Rajangan Madura tobacco national production?".

Robert H. Beach, Alison Snow Jones and Janet A. Tooze (2015) which discussed "Tobacco Farmer Interest and Success in Income Diversification" explained that the increase in productivity in the world of agriculture, especially tobacco cultivation, must be increased and expand the diversity of types of tobacco produced in order to reduce the need for imports carried out by the state with product updates / additional types of tobacco needed by the owners of capital in the world of agriculture. It is expected that it can reduce the policies of imports which have a bad impact on the local tobacco purchase price.

Antik Suprihanti, et al (2018) entitled "The Impact of Cigarette Excise Tax Policy on Tobacco Market and Clove Market in Indonesia ". indicates that the increase in excise taxes slightly reduced the production of kretek cigarettes. This resulted in a decrease in tobacco and clove consumption in the kretek cigarette industry by $0.06 \%$ and $0.05 \%$, respectively. The demand for tobacco and cloves continued to increase even in small quantities and increased the supply of tobacco but not cloves. In fact, the price of these commodities has actually decreased at the farm level, which indicated a gap caused by the oligopoly market structure of the cigarette industry. It indicated the dependence of farmers on the cigarette industry. It took cooperation between farmers and the cigarette industry as well as regulatory support from the government.

Hisnuddin Lubis (2014) studied the "Powerlessness of Madurese Tobacco Farmers in Madura Tobacco Trade System (study in Pamekasan Regency)" explains that Madura tobacco was one of the potential commodities with high economic value, even as a driving force for the regional economy. However, the reality was that Madurese tobacco farmers always sufferred losses and experience helplessness in every tobacco sale and purchase transaction. As a result of this fraudulent purchase of tobacco prices, the decline in Madurese tobacco production in a number of areas occurred, it was due to the fact that farmers expected profit but gained loss.

\section{RESEARCH METHOD}

This study used a qualitative approach, a research process to understand human (social) problems by explaining information from informants in detail and arranged in a scientific setting (Fatah, 2012). The research design used a descriptive style that provided a detailed description of the observed phenomena. The descriptive style was chosen because the researchers described and analyzed "Collaboration between Districts in Fulfilling Madura Rajangan Tobacco National Production".

The researchers used this theory because the theory expressed by Wright (1974) was very appropriate to measure the key to success of collaboration (cooperation) among governments (districts). The key measurement for the success of this Intergovernmental Relations is attempted to provide an evaluation of the collaborative path that 
was built together. The existence of an evaluation of the collaboration would minimize the failure of the program.

Sources of data in this study were obtained from literature studies or other information materials related to the problem in this study. This research was conducted on Madura Island, precisely in Pamekasan Regency, the choice of this location was due to the collaboration concept for the fulfillment of the national production of Rajangan Madura tobacco held at the Regional Coordination Board (BAKORWIL) of Pamekasan Regency.

The data collection techniques used in this study were as follows: (1) Observation, is the activity of observing certain things to find something that is desired based on its purpose. (2) Focus Group Discussion (FGD) is focus group, where information on a very specific problem is gathered through group discussions. (3) Literature study is all efforts made by researchers to gather information relevant to the topic or problem being studied or being studied. This information can be obtained from scientific books, research reports, scientific essays, theses and dissertations, regulations, regulations, yearbooks, encyclopedias, and written sources, both printed and electronic. Furthermore, to measure the validity of the data using data triangulation techniques, including data reduction, data presentation, and drawing conclusions (verification) (Huberman and Saldana, 2014)

\section{RESULTS AND DISCUSSION}

\section{Collaboration between Districts in} Fulfilling Rajangan Madura Tobacco National Production

To answer the questions in this study, the researchers used theory based on Wright (1974) in (Irawant, 2015). There are 5 key elements in the implementation of Intergovernmental Relations, namely:

The roles of government This focus put pressure on the IGR as an appropriate object for studying all permutations and combinations of relationships among units of government. Government units consisted of national, states, counties, municipalities, special districts and school districts.

The interactions of public officials, This second element indicates that there was no relationship among governments but only relationships among officials from different units of government. Interaction was observed through four sub-elements, namely, attitudes, beliefs, perceptions, and preferences of the personnel involved.

Sustainability communication, The third idea implicit in the IGR was that a relationship was not a one-time, occasional occurrence, formally ratified in treaties or rigidly established by law or court rulings. On the contrary, IGR was a pattern of contact, knowledge, and evaluation of government officials that were continuous from day to day. The main concern was with informal and formal practices and principles, pursued in a competitive and cooperative interjurisdictional pattern.

The roles administrators, Intergovernmental relations emphasize the important role played by all public officials engaged in cooperation such as elected officials and appointed administrators. Administrators were public officials appointed from both public authorities and authorities with special / professional functions. Meanwhile, the elected officials consisted of officials from the executive, legislative and judiciary fronts.

Focus attentions on the policy, This focus observed to what extent the government's attention to the cooperation carried out could affect general policies, especially in terms of fiscal policy. In this regard, there must be in-depth attention to the impact on local budgets, particularly from sub-elements such as financial issues (budgetary capacity), political support, and their impact on other policy areas. 


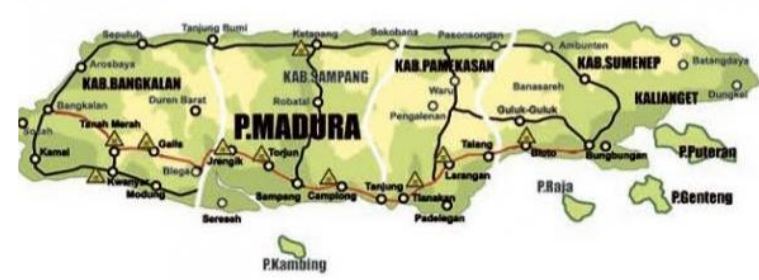

Figure 3. Madura Island

Madura Island is divided into four regencies. With an area for Bangkalan Regency 1,144, $75 \mathrm{~km}^{2}$ is divided into 8 sub-districts, Sampang Regency has an area of $1,321.86 \mathrm{~km}^{2}$, is divided into 12 districts, Pamekasan Regency has an area of 844.19 $\mathrm{km}^{2}$, which is divided into 13 sub-districts, and Sumenep Regency has an area of $1,857,530 \mathrm{~km}^{2}$, divided into $27 \mathrm{sub}$ districts spread over land and archipelago areas.

The relationship between the four districts on the island of Madura is currently in the context of establishing cooperation in the field of Madura tobacco farming. This relationship was forged to improve the welfare of tobacco farmers. This collaboration was expected to increase tobacco production in each region of Madura, which according to East Java Central Bureau of Statistics (BPS) data has decreased. The positive effects of this collaboration were very much from improving the welfare of tobacco farmers, increasing tobacco production and being able to eliminate price discrimination by the tobacco mafia (middlemen / collectors and others).

Collaboration between districts in fulfilling Rajangan Madura national tobacco production was fostering cooperation among regions using 5 elements of Intergovernmental relations, including 1) The role of the government, 2) The interaction of public officials, 3) Continuous communication, 4) The role of administrators, 5) focus on policy. In addition, it explained the factors that caused the decline in the production of Madurese Tobacco Slabs every year.
Madura is an archipelago in the administrative area of East Java Province. On the island of Madura, the majority of the community's work is farming, where most people are farmers of tobacco, salt and rice. So it was not surprised if the island of Madura is famous for the island of salt and the land of green gold the term has been named because the region of Madura is also the largest producer of tobacco in the archipelago from the Dutch colonial era besides Madura Island is also the center of a kretek cigarette factory and if the tobacco harvest period arrives, the factory those in the Madura region are competing to get tobacco that has been processed by farmers.

Madura Tobacco is also one of the most admired variants for its taste, aroma and purity. Madura tobacco farmers maintain their authenticity without any mixture of tobacco from other regions. It is what makes Madura tobacco superior to other tobacco.

In fulfilling national production of course, Pamekasan Regency cannot stand alone even though it is the largest tobacco producer in East Java Province, which annually produces around 18 tons of tobacco. The archipelago of Madura which consists of these four districts when viewed from the total production data in 2017 reaching 43 tons.

However the resulting production still does not meet the market needs. So Pamekasan District must establish cooperation between districts throughout Madura to jointly increase Madura tobacco production. With this increase in production, it will have a good impact on Regional Original Income (PAD) in each district and can also improve the welfare of tobacco farmers through established cooperation. To see how the relationship between districts throughout Madura can be seen from how intergovernmental relations works. This can be seen from the 5 key elements of intergovernmental relations expressed by Wright (1974) in 
(Irawanto, 2015). The explanation is as follows.

1) The role of goverments,

This aspect emphasizes the relationship among government units that exist in each region. The increase in madura tobacco production involved four districts on Madura Island, namely Bangkalan, Sampang, Pamekasan and Sumenep. In this collaboration, each district had its own role in its own region. With a role in this cooperation, each district needed a basis for regulation and support from related government agencies/ institutions, namely the Department of Industry and Trade. Pamekasan Regency is the initiator of the collaboration to Increase Madura Tobacco Production.

The interview with The Head of the Plantation Office of the Pamekasan Horticulture and Plantation Food Crops Service (Distan PHP) is as follows, Ahmad Suaidi said, regarding the decline in tobacco in Pamekasan Regency:

"The decline in Madura tobacco production in each district had decreased significantly, the amount of production produced by farmers had decreased by around 3.5 tons per year. This has spurred Distan PHP Pamekasan Regency to establish a collaboration with the existing districts on Madura Island in increasing tobacco production and the welfare of tobacco farmers through this collaboration ".

The objective of this collaboration is that Madura remains the largest tobacco supplier island in Indonesia with superior quality and quantity. The benefits that will be felt for each district in this collaboration are a) Welfare of tobacco farmers, b) Increasing Regional Original Income (PAD) in Madura Tobacco Agriculture and, c) Minimizing the movement of the tobacco mafia (cukong / collectors) which has led to lower prices among farmers.

The cooperation of the four districts was certainly $b$ felt by each element, even though the methods applied between regions in fulfilling tobacco production had differences. In addition, the Pamekasan Regency Government had provided input to the three districts which will strengthen this collaboration regarding the existence of the Madura Tobacco Regulation, with the existence of regulations related to Madura Tobacco that made it easier to achieve the goals of the existing collaboration.

In this regulation the main objective was to improve the welfare of tobacco farmers and to make Madura Tobacco a regional superior commodity.

2) The interaction of public officials,

Interaction of public officials in cooperation among regions is important because it will determine the continuation of cooperation. The interaction was observed from four sub elements, namely behavior, beliefs, perceptions and preferences of the apparatus involved. The following is a detailed description of each sub-element, namely:

a) Behavior

This aspect showed the attitude of the official from each of the parties involved in the cooperation. The attitude of officials from each district government on the island of Madura shows an attitude that is optimistic about the success in fulfilling Madura tobacco production in every district area.

b) Trust

Trust was the most important aspect in establishing a collaboration. This collaboration was established with mutual trust between district governments. It was evident in the responsibilities of each party in carrying out their roles and obligations to the tobacco farming community.

c) Perception

This aspect was to observe the understanding of each party about the importance of cooperation between regions in fulfilling the national production of Madura Rajangan tobacco. Each local government saw that progress in the agricultural sector will increase the PAD of each district government and can make tobacco farmers prosperous. 


\section{d) Preference}

The preference aspect shows the tendency of each party involved in cooperation. The preference of each district involved in cooperation is to preserve and cultivate native Madura tobacco plantsas a commodity superior area.

1) Sustainability communications,

Communication between local officials in cooperation is very important. The interactions that are carried out between District officials on a regular basis indicate continued communication.

The following is the explanation of the Head of the Pamekasan Horticultural and Plantation Food Crops Service (Distan PHP), Ajib Abdullah, ST., M.Si. related to communication between Pamekasan Regency offices with other districts:

"The interaction continues to run well in accordance with the mutual agreement to increase Madura tobacco production in order to meet the increasing market demand and strive together to be able to import Madura tobacco to neighboring countries".

When viewed from the frequency of communication, cooperation between regions in the Fulfillment of National Tobacco Production in Rajangan Madura had carried out routine communication with meetings through certain scheduling conducted by the Industry and Trade Service and the Pamekasan Regency Agriculture Office where this meeting place was often scheduled at the Regional Coordination Agency (BAKORWIL) Pamekasan Regency.

2) The roles of administrastor,

The implementation of cooperation between regions in Fulfilling the National Tobacco Production of Rajangan Madur cannot be separated from the role of executive and legislative officials. The role of executive officers at the regional level was a key actor in implementing cooperation. It can be seen in the executive branch that had given the mandate to the head of the department to collaborate so that the cooperation can continue. Meanwhile, the legislative role was related to the budget used in implementing cooperation. It was due to the budgeting function was in the hands of the legislature, so the budget as a result of this collaboration must obtain legislative approval.

In addition, the duties of the legislature for regions that did not have regulations on Madura Tobacco must be formulated first so that in regional policies in preserving and cultivating native Madura tobacco planted as superior commodities in this region there was a legal umbrella and can walk well for the cooperation carried out.

Mr. Fathorrahman, M.Si as Chairman of the Pamekasan Regency Regional People's Representative Assembly (DPRD) revealed that:

"For the time being, the regency that regulates Madura tobacco in terms of trading, cultivation and protection is only Pamekasan Regency, all of which are listed in Regional Regulation No. 4 of 2015 concerning Administration, Cultivation and Protection of Madura Tobacco with the aim of a) Preserving and cultivating native Madurese tobacco plants as a regional superior commodity; b) Protecting the authenticity of Madura Tobacco; and c) Creating order to protect and improve the welfare of farmers, traders and local income. It will become a reference in cooperation between districts, and each district will start the formulation of a regional regulation on Madura tobacco for their respective regions based on the aspects of trade, cultivation and protection of Madura tobacco "

3) Focus on the policy

Every program and activities for the fulfillment of Rajangan Madura Tobacco National Production sourced from the respective parties involved. In the implementation of cooperation, each party 
did not make a specific budget allocation for cooperation, but each district formulates each budget that must be provided in the Madura tobacco production fulfillment program.

In this collaboration among districts on Madura Island, it only discussed the ways or solutions so that Madura remained the largest tobacco producer in the national scope and by fulfilling this production it can attract many manufacturers to work together to buy tobacco from farmers, so that farmers' welfare is guaranteed.

After analyzing the relationship between districts in increasing Rajangan Madura tobacco production, then further examined the factors causing the decline in Madura tobacco production rates that occurred from year to year in each region of the island of Madura.

\section{Factors Causing Decreased Production of Farmers in Producing Rajangan Madura Tobacco}

With the literature study about madura tobacco as well as seeing the results of observations and focus group discussions (FGD) with several stakeholders directly related to Madura tobacco, which is a factor causing the decline in farmer production in producing Madura Rajangan tobacco, among others, are as follows:

First, falling tobacco prices were a major factor for farmers in producing tobacco. Farmers felt aggrieved because the hope of being able to get a big profit from tobacco farming had vanished again because of the price play made by collectors or cukong. This price volatility made farmers switch to other crops and were reluctant to cultivate Madura tobacco again.

Monopoly in the tobacco trade system was a nightmare for farmers, because those who would suffer losses were the lower classes (farmers). Therefore with the collaboration between districts, it is expected that it will synergize supervision in the tobacco trade system, so that the stability of Madura tobacco prices will have a good impact on increasing the production of tobacco farmers.

Second, climatic factors also influenced the maturation process of tobacco until it was ready for harvest. If the tobacco season was decorated with high rainfall, it would affect the quality of tobacco, not only that factories would be reluctant to buy Madura tobacco from farmers or collectors.

Third, reduced land owned by the government and the community due to the fulfillment of local government infrastructure development such as parks, official offices, soccer fields, activation of land at Madura airport and other public facilities. For land owned by farmers due to the construction of community settlements (housing) and the conversion of land functions, all plantation land (rice fields) had become shopping centers, home factories and others.

\section{CONCLUSION}

The relationship that existed among the regions involved in the collaboration was carried out by dividing the roles of each area. The interaction of public officials showed that there was cooperation in behavior, beliefs, perceptions and preferences. With regard to the communication built from the four regions, looking for ways and solutions to be able to increase Madura tobacco production in each district, in addition, it also solved the problems faced every year where the price of Rajangan Madura tobacco often dropped, due to games from the parties. collectors. With a meeting of public officials / related agencies, they can exchange ideas and ideas to give good things to the agricultural sector, especially Madura tobacco.

\section{BIBLIOGRAPHY}

Djaja, (2018). Peningkatan Produksi dan Mutu Tembakau Madura Melalui Inovasi Teknologi dan Dukungan Kebijakan. Jakarta. IAARD Press. 
Fatah, M. (2012). Metode Penelitian. Jakarta. Ghalia Indonesia.

Hakim, N.F \& Wibisono, G. (2017). Social Capital of Tobacco Farmer for Social Welfare Improvement. Jurnal PKS. 16(4): 369-380.

Hammam, R.H. (2015). Proses Pemasaran Hasil Pertanian Tembakau (Studi Kasus Pada Proses Pemasaran Hasil Pertanian Tembakau Di Desa Mandisari Kecamatan Parakan Kabupaten Temanggung). Artikel E-Journal. Universitas Negeri Yogyakarta.

Hamzah, A. (2017). PTK Qualitative Quantitatif atau Mixed. Yogyakarta. Deepublish.

Handaka, T \& Surokim. (2015). Pola Komunikasi Kelompok Petani Tembakau Madura sebagai Basis Penyususnan Kebijakan Pemberdayaan Ekonomi Politik. Jurnal Ilmu Komunikasi. 10(7): 67-88.

Hasan, F dan Darwanto, D.H. (2013). Prospek dan Tantangan Usaha Tani Tembakau Madura. Jurrnal SEPA. 10(1): 63-70.

Irawanto, (2015). Intergovernmental Relations and Dilema of the Cooperation. Journal of Basic Applied Scientific Research, 5(8): 76-85.

Lubis, H. (2012). Ketidakberdayaan Petani Tembakau Madura Dalam Tataniaga Tembakau Madura (Study Di Kabupaten Pamekasan). Jurnal Agro Ekonomi. 26(1): 90121.
Miles, M., Huberman, A., \& Saldana, J. (2014). Qualitative Data Analysis, A Methods Sourcebook (3rd ed.; Tjetjep Rohindi Rohidi, ed.). Jakarta: UI-Press.

Nurwiyati, R.T., dan Yuwanto. (2017). Peran Asosiasi Petani Tembakau Indonesia (APTI) Dalam Memperjuangkan Kepentingan Petani Tembakau Di Kabupaten Temanggung. Universitas Diponegoro Semarang.

Peraturan Daerah No 4 Tahun 2015 Tentang Tata Niaga, Budidaya dan Perlindungan Tembakau Madura.

Santoso, T. (2012). Tataniaga Tembakau Di Madura. Jurnal Manajemen dan Kewirausahaan. 3(2): 96-105.

Undang-undang No 23 Tahun 2014 Tentang pemerintah Daerah.

\section{Website :}

Https://id.wikipedia.org/wiki/Tembakau Https://jatim.bps.go.id/pencarian.html?searching= indeks+data+tembakau\&yt $1=$ Cari

Https://pamekasankab.bps.go.id/statictable/2017 /06/09/238/produksi-produktivitas-dan-luasareal-tanaman-perkebunan-tembakau-menurutkecamatan-di-kabupaten-pamekasan-2015.htm 